\title{
Distribution and
}

\section{Abundance of Muskoxen North of Great Bear Lake}

\author{
JOHN P. KELSALL, ${ }^{1}$ VERNON D. HAWLEY ${ }^{1}$ \\ AND DONALD C. THOMAS ${ }^{2}$
}

\begin{abstract}
Heavy exploitation until about 1910-11, so drastically reduced muskoxen populations that they were thought to be extinct, or nearly so, north of Great Bear Lake. Following a few earlier sightings, they have been seen with increasing frequency since 1953. They now occupy, with one major exception, the areas where they were known to have been plentiful, and their population is estimated to be at least $\mathbf{4 2 5}$ animals.
\end{abstract}

RÉSUMÉ. Distribution et abondance du bœuf musqué au nord du Grand lac de l'Ours. Jusque vers 1910-11, la chasse excessive du bœuf musqué avait tellement réduit les populations de cet animal au nord du Grand lac de l'Ours, qu'on les croyait éteintes ou presque. Depuis 1953 et à la suite de quelques observations plus anciennes, on a aperçu ces groupes avec une fréquence croissante, si bien qu'ils occupent maintenant, à une exception près, toutes les aires où ils furent jadis nombreux. Leur population est estimée à au moins 425 têtes.

РЕЗЮМЕ. Распределение мускусных быков в районах иа север от Болъиого Медвемьъео озера. Бесконтрольное истребление мускусных быков до того истопило резервы этих животных, что они долгое время считались полностью исчезнувшими в районах на север от Большого Медвежьего озера. Начиная с 1953 г., численность мускусных быков снова стала возрастать и в настоящее время они встречаются почти во всех тех районах, в которых они были многочисленны в прошлом. По имеющимся данным популяция мускусных быков теперь насчитывает не менее 425 жиивотных.

\section{INTRODUCTION}

The muskoxen (Ovibos moschatus) north of Great Bear Lake to the arctic coast, and west of Coppermine River, have long been of interest to northern travellers and wildlife biologists. They are the westernmost indigenous muskoxen in North America. Their early history has been documented by Preble (1908), Hoare (1930), Anderson (1934), Clarke (1940), and Tener (1958). In the latter half of the nineteenth century the animals were abundant in the general area of the Dismal Lakes; along the arctic coast from Liverpool Bay to Darnley Bay; and, particularly in winter, on the upper regions of the Anderson and Horton Rivers.

Whalers wintering on the coast used them for food - Anderson (in Hoare 1930) tells of over 80 animals taken in the winter of $1897-98$ by the crews of four ships in Langton Bay. Indians and Eskimos also took muskoxen for food, and for an extensive trade in hides at Fort McPherson, Fort Norman, Fort Good Hope and at now long-abandoned Fort Anderson. That trade flourished particularly

1Canadian Wildlife Service, Edmonton, Canada.

2Anatomy Department, Cambridge University, England. 
during the last two decades of the nineteenth century (Tener 1965). Muskoxen have been protected in Canada only since 1917.

By the end of the century, the remaining animals were confined to the area just north of Dease Arm on Great Bear Lake and Dease River where a few were still being killed up to 1910-11. The late D'Arcy Arden of Yellowknife, Northwest Territories, who lived many years near the mouth of Dease River, told Kelsall that the last of those animals were apparently taken by Coppermine Eskimos during the First Great War.

For many years after, there were no authentic reports of muskoxen from the entire area, and they were thought to be extinct. In 1930, Anderson suggested two or three were left in the entire area north of Great Bear Lake, and west of Coronation Gulf. Clarke (1940) based his estimate of 50 animals in the area on reports in 1930 and 1933. In 1949 the Royal Canadian Air Force reported a band of 10 near Bluenose Lake. In 1953, Kelsall photographed 86 animals in 3 groups near the headwaters of the Horton River. Since then, the animals have been reported almost yearly. Tener (1965) assessed their numbers, from reports up to 1961 at ". . . about 100 in the Bluenose Lake area north of Great Bear Lake and about 200 south of Paulatuk on the Arctic coast." This was the most comprehensive assessment of numbers and distribution to that time.

\section{METHODS}

Reliable reports of muskoxen north of Great Bear Lake are by-products of aerial and ground surveys of caribou carried out by the Canadian Wildlife Service since 1953. These include a partial survey of the area in February 1953, a limited air and ground survey in August and September 1953 (Kelsall 1970), and a survey of nearly the whole area in March 1955, by Kelsall; a search for caribou in the southwestern portion of the area in March 1958, by Thomas; a survey of the whole area in March 1966, by Hawley; and a search of most of the area in early March and late April 1967, by Thomas (1969). We feel that these surveys accurately determine the late winter distribution of muskoxen in most parts of the region, and provide a basis for reasonable estimates of population numbers. Of the few records from other seasons of the year, those particularly relevant to our discussion are shown in Fig. 1.

\section{RESULTS AND DISCUSSION}

\section{Distribution}

Our observations of muskoxen in the late winter are plotted on the map, Fig. 1. Most observations are concentrated about the headwaters of the Horton River, and between Horton Lake and the region south of Bluenose Lake. Of 76 animals seen in 4 observations west of the Horton River some, curiously, were within treeline. All these observations are in country rarely visited by Indians and Eskimos, primarily because precipitous river gorges cut through the terrain. The herds are remote from the Indians at Colville Lake and the Eskimos at Coppermine and Darnley Bay. 


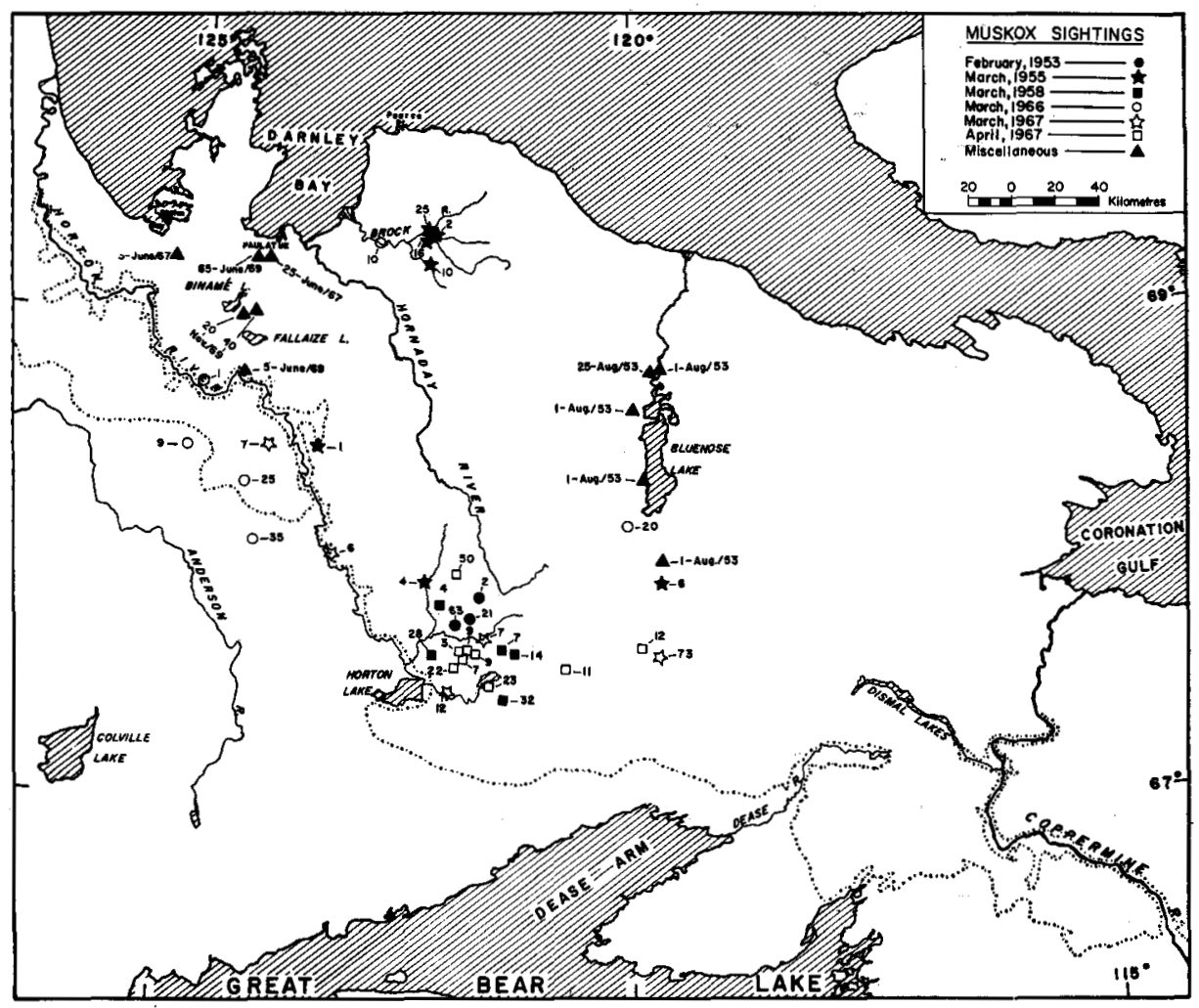

FIG. 1. Position and numbers of muskoxen observed north of Great Bear Lake since 1953. Dotted line indicates northward limit of trees.

The discovery of dozens of wintering muskoxen on the lower reaches of the Brock River was a surprise. This area is not many kilometres from Darnley Bay where are situated Eskimo camps and the village of Paulatuk. But the animals were probably safe from human interference there because precipitous banks and boulderstrewn valley bottom make the Lower Brock River a difficult place for Eskimos to travel.

The muskoxen seen just south of Paulatuk, in June 1967 and 1969, were not observed during our winter surveys. They may have become established since 1955, and are now apparently year-round residents. As recently as November 1969, two groups of 20 and 40 individuals were reported between Binamé and Fallaize lakes. Enquiries at Paulatuk and Pearce Point in 1955 disclosed not one Eskimo who knew muskoxen were so near in winter, either south of Paulatuk or on the Brock River.

A few animals probably winter regularly in, or close to the large valley of Bluenose Lake, which has never been completely surveyed in winter. Kelsall saw winter-type feces there in August $1953($ Kelsatl 1970). The use of wintering areas may vary from year to year. The survey in 1966 failed to locate muskoxen near Horton Lake, but drifting snow near ground level was so bad when the transects 
were flown that the resident animals may have been missed. In 1955, we did not intensively survey the Horton Lake area, and saw no muskoxen there.

Most of the spring and summer observations shown on the map are from regions where the animals have not been seen in winter. The muskoxen north of Great Bear Lake probably summer in the luxuriant valleys of major lakes and rivers and winter on the relatively snow-free uplands, like the muskoxen of the Thelon Game Sanctuary (Tener 1965).

TABLE 1. Winter observations of muskoxen north of Great Bear Lake since 1953.

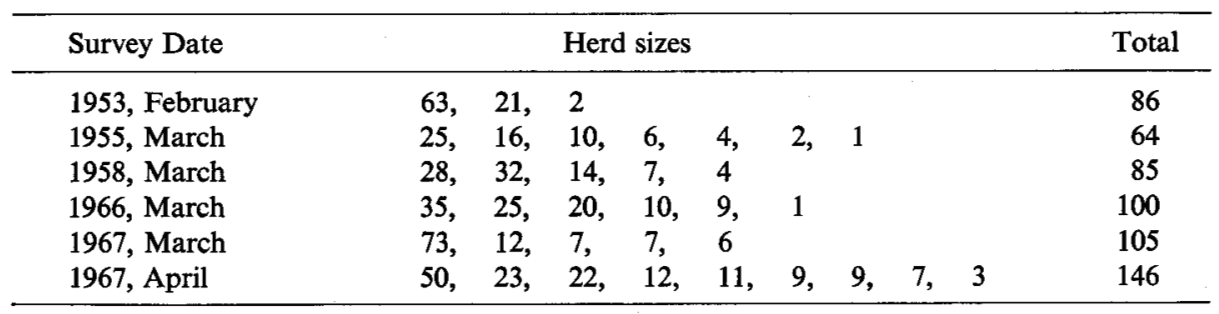

\section{Numbers}

Table 1 gives the total numbers and the number and sizes of the individual herds of animals seen on our various surveys. Muskoxen are usually contagiously distributed with most being included in one to three large herds and the balance in groups of a dozen animals or less. Contagious distribution, and the fact that muskox are visible at much greater distances than barren-ground caribou, calls for caution in extrapolating census statistics applicable to caribou to calculate a total muskox population. Thus, after his 1955 survey, Kelsall calculated that he had surveyed about 15 per cent of the muskox range north of Great Bear Lake. On that basis, the 64 muskoxen could theoretically be extrapolated to a population of 425 animals plus about 100 because the Horton Lake area was not surveyed.

In 1966, Hawley and his observers surveyed the country on transects (primarily east-west) at 40.2-kilometre intervals. If we assume that they saw all muskoxen within 3.2 kilometres of either side of the aircraft, then they surveyed 16 per cent of the range, and the estimate of the muskox population would be 625 animals.

It is probably safer to combine high counts in some areas with a little judicious speculation in others and the assumption that animals repeatedly use the same

TABLE 2. Estimated population of muskoxen north of Great Bear Lake.

\begin{tabular}{lc}
\hline Location & Estimated numbers \\
\hline Binamé Lake - high count June 1969 & 65 \\
Brock River area - high count 1955 & 53 \\
Bluenose Lake - estimated from summer 1953 & 30 \\
Horton Lake - high count 1967 & 134 \\
South of Bluenose Lake 1967 & 73 \\
Horton-Anderson Rivers 1966 & 70 \\
\hline Total & 425 \\
\hline
\end{tabular}


winter ranges and their numbers change slowly. Using these criteria, we arrive at the population estimate shown in Table 2.

The total estimate is almost certainly conservative. Although most regional estimates are believed accurate, more muskoxen may be scattered throughout the vast Great Bear Lake region, and many more than we have seen may be in the rough, and partially forested, Horton-Anderson River area.

\section{CONCLUSIONS}

The muskoxen north of Great Bear Lake have increased in number, and extended their range in the past 40 to 50 years. The area north of Dease River and toward Dismal Lakes, where they are known to have been plentiful, is the only one not yet repopulated.

There is every indication that the animals will continue to increase and spread. We have a strong suspicion that the population in the Binamé-Fallaize lake area has established itself as a thriving entity since 1955. In addition, our observations of recruitment suggest good calf crops in at least 1953 and 1967, and good survival of young animals in the two or three years preceding those dates. Increased numbers will no doubt result in extension of the range.

We are certain that a systematic survey, particularly west of the Horton River, would reveal animals in excess of our high count of 70, as well as additional animals in other areas.

\section{ACKNOWLEDGEMENTS}

Most original observations were by-products of research projects conducted by the Canadian Wildlife Service on the barren-ground caribou. We are indebted to Dr. T. W. Barry for summer observations of muskoxen in 1967 and 1969.

\section{REFERENCES}

ANDERSON, R. M. 1934. The distribution, abundance, and economic importance of the game and fur-bearing mammals of Western North America. Proceedings of the 5th Pacific Science Congress, 1933: 4055-75.

CLARKE, C. H. D. 1940. A biological investigation of the Thelon Game Sanctuary. National Museum of Canada Bulletin 96, Biological Series 26. 135 pp.

hoARE, W. H. B. 1930. Conserving Canada's musk-oxen. Canada Department of the Interior. $53 \mathrm{pp}$.

KELSALI., J. P. 1970. Observations of birds and mammals at Bluenose Lake, N.W.T. Arctic, 23: 190-96.

PREBle, E. A. 1908. A biological investigation of the Athabasca-Mackenzie Region. U.S. Department of Agriculture, North American Fauna, 27.574 pp.

TENER, J. S. 1958. The distribution of muskoxen in Canada. Journal of Mammalogy, 39(3): 398-408.

\section{Muskoxen in Canada. Canadian Wildlife Service Monograph 2. 166 pp.}

THOMAS, D. C. 1969. Population estimate and distribution of barren-ground caribou in Mackenzie District, N.W.T., Saskatchewan and Alberta - March to May, 1967. Canadian Wildlife Service, Report Series No.9.44 pp. 